\title{
Trials for Control of Pseudomonas Septicemia in Tilapia Zillii Using Tumeric Powder as A Medicated Feed
}

\author{
Eissa I. A. M. ${ }^{*}$, Takwa Ismail**, Fatma Yousseff**, Shimaa Mansour** \\ *Dept. of Fish Diseases and Management, Fac. of Vet. Medicine, Suez Canal \\ Univ. **Animal Health Research Institute, Ismailia branch. \\ *eissavet29@yahoo.com \\ **aimantouny@yahoo.com \\ **Fatmayousseff@yahoo.com \\ **dr shimaamansour2014@yahoo.com
}

\begin{abstract}
The present study aimed to investigate the effect of different concentrations of curcumin in fish diet on blood parameters and disease resistance against challenge with pathogenic bacterial agent Pseudomonas aeruginosa. A total number of 120 apparently healthy Tilapia zillii, weighting $35 \pm 5$ gram were divided into four groups. Each group consisted of 30 fish, each was subdivided into 3 subgroups (10 fish/sub group) in well prepared glass aquaria with water daily changed and fed at 3\% body weight per day. The first group fed on basal diet without any supplementation with turmeric powder and served as control group. The second (T1), third (T2) and fourth (T3) groups were fed on the same basal diet supplemented with turmeric powder with different concentrations $2(0.20 \%), 5$ $(0.50 \%)$ and $10 \mathrm{~g} / \mathrm{kg}(1 \%)$ respectively for 30 days. At the end of this period, five fish from all groups were sampled for blood indices for differentiation between basal diet and supplemented diet. After the end of the experiment, fish in all groups were intraperitoneally (IP) challenged with Pseudomonas aeruginosa then blood samples were collected to investigate the effect of turmeric powder on hematological parameters of experimentally infected fish fed onto supplemented and basal diet. The mortality rate after challenging with Pseudomonas aeruginosa were decreased in all treated groups than control group.
\end{abstract}

Keywords: Tilapia zillii, Turmeric (Curcuma longa), Pseudomonas aeruginosa.

\section{Introduction}

Without doubt, Bacterial diseases were responsible for heavy mortality in wild and cultured fish.
The problems in the fish farms are usually tackled by preventing disease outbreaks or by treating the actual disease with drugs or 
chemicals and the use of antimicrobial agents had increased significantly in aquaculture practices (Smith et al., 1994).

Medicinal plants act as the alternative agents which were effective to treat the infectious diseases and mitigated many to side effects that were associated with synthetic antimicrobials

\section{(Direkbusarakom, 2004).}

Turmeric, Curcuma longa L., belongs to the family Zingiberaceae and considered one of the most important medicinal plants across the world and contained many compounds, such as curcumin, turmerone, curcuminoids, turmerone, arturmerone, and zingiberene, that had been antioxidant activities (Selvam et al., 1995). Curcumin was orangeyellow phytochemical, hydrophobic and polyphenolic compound of turmeric (Curcuma longa Linn.) (Behera et al., 2011)

Curcumin considered as the main constituent of turmeric that has multiple pharmacological activities included antimicrobial, antiinflammatory, anticancer, hepatoprotective, antimutagenic, immunomodulatory and antioxidant effects but its widespread clinical applications had been limited due to poor aqueous solubility and minimal systemic bioavailability (Moghadamtousi et al., 2014).

Curcumin was needed for treatment of most diseases as it was inexpensive and extremely safe even at very high doses (Lao et al.,
2006). Turmeric powder could inhibit the growth of histamineproducing bacteria as Vibrio parahaemolyticus, Bacillus cereus, Pseudomonas aeruginosa, and Proteus mirabilis (Paramasivam et al., 2007).

The present study was planned to investigate the effect of different concentrations of curcumin in fish diet on blood parameters and disease resistance against challenge with pathogenic bacterial agent Pseudomonas aeruginosa.

\section{Material and Methods}

\section{Experimental Fish}

A total number of 120 apparently healthy Tilapia zillii were collected alive with an average body weight $35 \pm 5 \mathrm{~g}$. These fish were used for experimental infection. Fish were collected from Fish Research Center, Suez Canal University, Ismailia governorate. They were transported in well aerated tanks filled with their natural water to the laboratory of Department of Fish Diseases and Management, Faculty of Veterinary Medicine, Suez Canal University. Fish were kept in glass aquaria measuring $(80 \times 40 \times 30 \mathrm{~cm})$. These aquaria supplied with their natural water according to Innes (1966) and conducted with electric air pumping to obtain continuous aeration. Water temperature was controlled and adjusted at $25 \pm 1{ }^{\circ} \mathrm{C}$ via thermostatic heaters. Fish used for experimental infection were acclimated for two weeks, during this period fish were fed a basal diet only at $3 \%$ of body weight. 


\section{Experimental diets}

The basal diets (commercial pelleted diet) were formulated to supply $32 \%$ crude protein and 4000 kcal digestible energy (DE)/kg diet. Tumeric powder (TP) was obtained from a local market. Tumeric powder (TP) was weighed, added with different concentrations to the commercial pelleted diet to represent 2, 5g/kg (Abdel Tawwab and Fayza, 2017) and $10 \mathrm{~g} / \mathrm{kg}$ (Amany Diab et al., 2014) diet levels and mixed well by using of oil. The pellets after addition of turmeric powder were allowed to be air dried by electric fan at room temperature for $24 \mathrm{hr}$ then packed in plastic bags and refrigerated at 4 ${ }^{\circ} \mathrm{C}$ until use (Hassan et al., 2018).

\section{Experimental design}

A total number of 120 apparently healthy Tilapia zillii, weighting 35 \pm 5 gram were divided into four groups. Each group consisted of 30 fish; each was subdivided into 3 subgroups (10 fish/sub group) in well prepared glass aquaria with water daily changed. The first group (T1) fed on basal diet without any supplementation with turmeric powder and served as control group. The second (T2), third (T3) and fourth (T4) groups were fed on the same basal diet supplemented with turmeric powder with different concentrations $2(0.20 \%), 5(0.50 \%)$ and $10 \mathrm{~g} / \mathrm{kg}(1 \%)$ respectively for 30 days. Fish were fed $3 \%$ of their body weight and the diets were offered twice per day. At the end of this period, five fish from all groups were sampled for blood indices for differentiation between basal diet and supplemented diet on the chemistry of fish blood.

\section{Challenge test}

\section{A. Preparation of bacterial inoculum}

Pseudomonas aeruginosa was previously isolated from organs of naturally infected and freshly caught marine fish including seabass (Dicentrarchus labrax) and Tilapia zillii which were collected randomly from Lake Temsah in Ismailia governorate. The most isolated bacteria were Pseudomonas aeruginosa which identified by using traditional methods and Vitek 2 system.

$P$. aeruginosa was inoculated into nutrient agar and incubated at $37^{\circ} \mathrm{C}$ for 24 hrs. Bacterial colonies were collected in sterile saline $(0.85 \%$ $\mathrm{NaCl})$. According to Iqbal et al., (1999), each $\mathrm{ml}$ of saline contained $3 \times 10^{7} \mathrm{cfu} / \mathrm{ml}$ (LD50 by using McFarland standard tube according to Ezzat et al., (2018).

\section{B. Injection of the bacterium inoculum}

After the end of the experiment, fish in all groups were intraperitoneally (IP) challenged with $0.2 \mathrm{ml} /$ Fish of a bacterial suspension of $P$. aeruginosa.

After injection, blood collected from 5 fish from each injected group in second day after injection for evaluation the effect of curcumin onto the nonspecific innate immunity of fish. Day 3 was chosen as sample time as the 
previous studies have shown that the 3rd days showed peak levels of bacterial growth according to Raida and Buchmann (2009). Mortality and morbidity rates were monitored daily for one week. Specific mortalities were recorded by plating the aseptic samples of skin lesions, liver, kidneys and gills from the moribund fish on Pseudomonas $\mathrm{F}$ agar.

\section{C. Haematological analysis}

Blood was collected by heart puncture of the fish using heparinized syringe into small sterilized vials containing anticoagulant (Cal heparin), which were

used to estimate the haematological parameters as erythrocytic count, total

leukocytic and differential count, haemoglobin content and haematocrite value. Plasma was collected after centrifugation (3600 $\mathrm{g}$ for $5 \mathrm{~min}$ ) and stored in the deep freezer at $-70^{\circ} \mathrm{C}$ to determine total proteins, albumin and globulins

according to Ericsson and Nister (2011).

\section{Statistical Analysis}

The obtained data were statistically analyzed by an ANOVA (one way) variance method considering $\mathrm{P}<$ 0.05 using MiniTab17@ software. The significant differences were taken to Fisher multiple range tests to compare the means (Ryan and Joiner, 2005).

\section{Results}

\section{Mortality rates}

The mortality rates in experimentally infected Tilapia zillii with Pseudomonas aeruginosa after feeding on basal diet supplemented with different concentrations of curcumin as 2, 5 and $10 \mathrm{~g} / \mathrm{kg}$ representing 40, 20 and $10 \%$ respectively which were decreased than in control group (80\%).

\section{Clinical signs and Postmortem lesions}

The clinical signs in the experimentally infected Tilapia zillii were represented as hemorrhages distributed all over the body surface, lower jaw, base of fins, redness around eyes and erosion of fins The postmortem examination in those fish revealed congested to enlarged internal organs as liver, spleen, kidneys, gall bladder as shown in (Plate. 1).

Hematological parameters of experimental fish fed onto supplemented diet and basal diet before infection

The hematological parameters belong to the four examined groups (T1, T2, T3 and T4). As it is obvious, non-significant increase in concentration of hemoglobin $(\mathrm{Hb})$, counts of RBCs and hematocrit value (HCT) were observed in fish fed on diet containing $1 \%$ (T4) turmeric powder when compared with other experimental groups $(\mathrm{p}<0.05)$ as shown in (Fig. 1).

There were non-significant differences in the $\mathrm{MCV}, \mathrm{MCH}$ and $\mathrm{MCHC}$ 
values among experimental groups as shown in (Fig. 2).

The WBCs count was non significantly increased in fish group fed on diet containing $1 \%$ turmeric powder as compared with other experimental groups while lymphocyte percentage was tended to be a significant increase in fish group fed on diet containing $1 \%$ turmeric powder than fish group fed on diet supplemented with $2 \mathrm{~g} / \mathrm{kg}$ turmeric powder and also control group . On the other hand, there was non-significant decrease in percentage of neutrophils and monocytes in all supplemented groups than control group as shown in (Fig. 3).

The total proteins and globulins were significantly increased in fish fed on diet containing 0.50 and $1 \%$ turmeric powder than other groups $(\mathrm{p}<0.05)$ while albumin tended to be non-significant increase in all supplemented groups than control group as shown in (Fig. 4).

Hematological parameters basal and supplemented diet on the experimentally fishes after infection

The hematological parameters as a response to Tilapia zillii with intraperitoneal injection by well identified

Pseudomonas

aeruiginosa. The $\mathrm{RBC}$ count, $\mathrm{Hb}$ concentration, and HCT level increased significantly in the groups fed on supplemented diet with curcumin especially fish group fed on diet containing 1\% turmeric powder when compared with the control group as shown in (Fig. 5).

There were non-significant differences in the MCV, MCH and MCHC values among experimental groups as shown in (Fig. 6).

All the experimental groups fed on supplemented diet with Tumeric powder showed the WBCs count, percentage of neutrophils and lymphocytes were significantly increased in fish group fed on diet containing $1 \%$ turmeric powder when compared with other experimental groups $(p<0.05)$. On the other hand, there was a significant decrease in percentage of monocytes in all supplemented groups than control group as shown in (Fig. 7).

The total proteins, albumin and globulins were significantly increased in fish fed on diet containing $1 \%$ turmeric powder than other experimental groups as shown in (Fig. 8). 


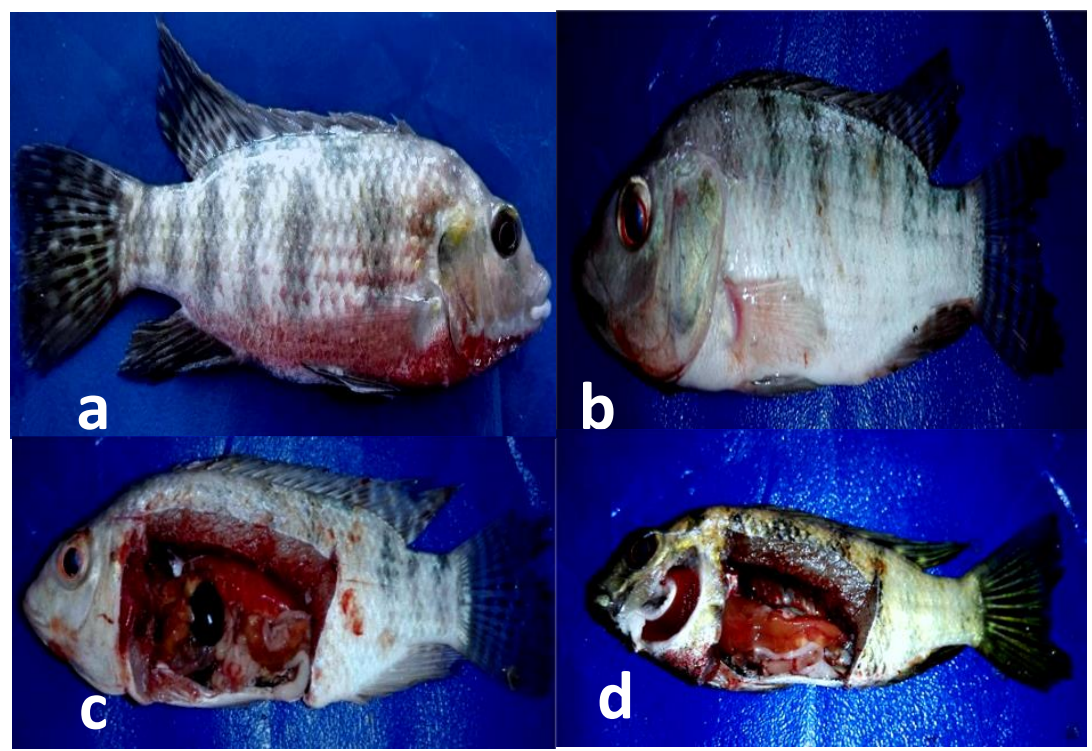

Plate. (1): Showing experimentally infected Tilapia zillii with Pseudomonas aeruginosa a) suffered from hemorrhages distributed all over the body surface and fins. b) redness around eyes and erosion of fins. c) and d) suffered from hemorrhages and enlargement in different internal organs.

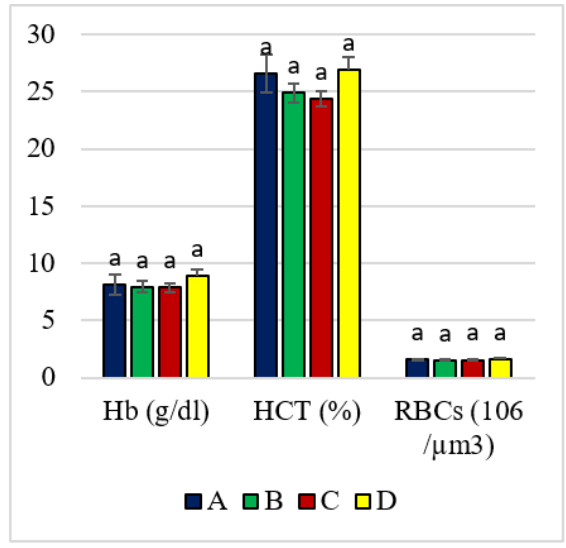

Figure (1): Hematological parameters $\left(\mathrm{Hb}(\mathrm{g} / \mathrm{dl}), \mathrm{HCT}(\%), \mathrm{RBCs}\left(10^{6} / \mu \mathrm{l}\right)\right.$ of experimental fishes fed onto supplemented diet and basal diet before infection

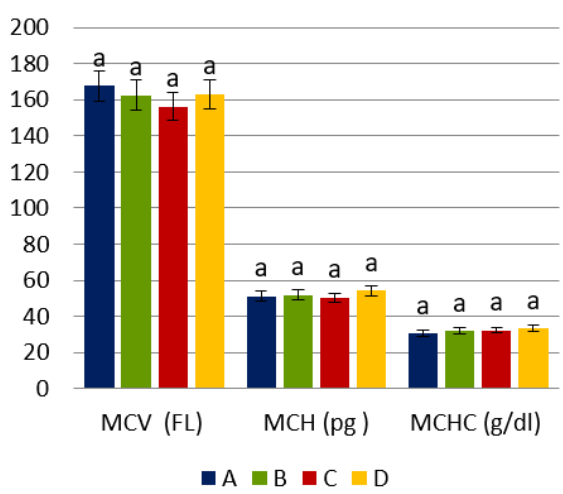

Figure (2): Hematological parameters ( $\mathrm{MCV}(\mathrm{FL}), \mathrm{MCH}(\mathrm{pg}), \mathrm{MCHC}(\mathrm{g} / \mathrm{dl})$ ) of experimental fishes fed onto supplemented diet and basal diet before infection 


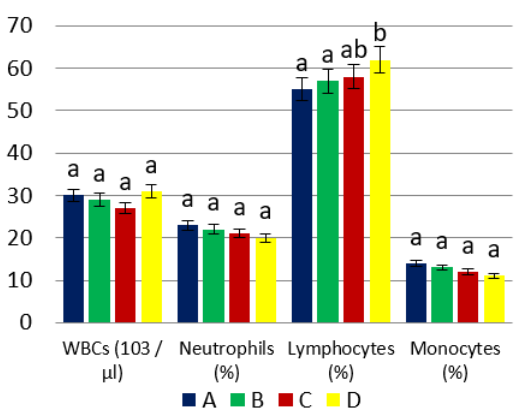

Figure (3): Hematological parameters (WBCs $\left(10^{3} / \mu \mathrm{l}\right)$, Neutrophils (\%), Lymphocytes (\%), Monocytes (\%) of experimental fishes fed onto supplemented diet and basal diet before infection

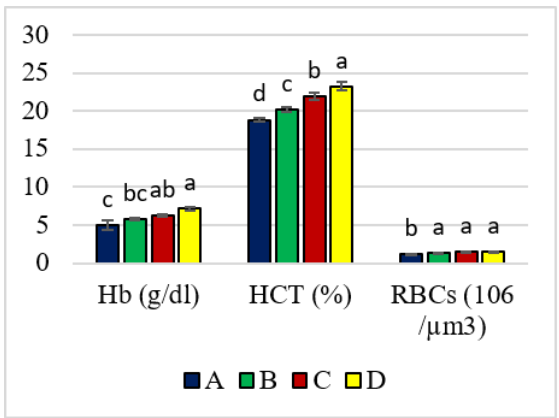

Figure (5): Hematological parameters (Hb) $\left.(\mathrm{g} / \mathrm{dl}), \mathrm{HCT}(\%), \mathrm{RBCs}\left(10^{6} / \mu \mathrm{l}\right)\right)$ of experimental infected fish fed onto supplemented diet and basal diet

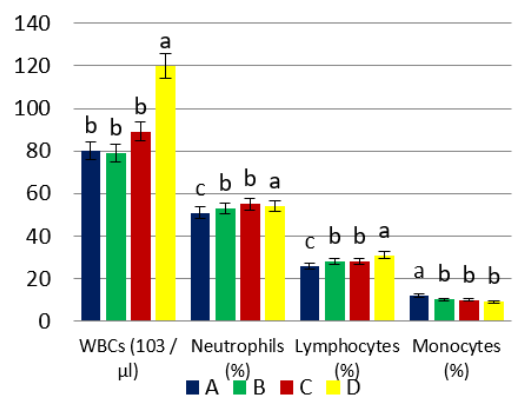

Figure (8): Blood Proteins of experimental infected fish fed onto supplemented diet and basal diet.

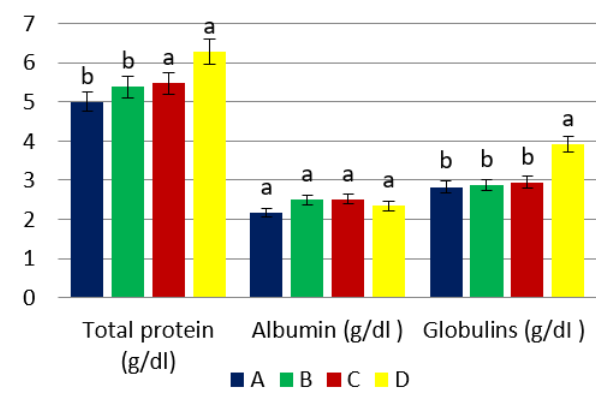

Figure (4): Blood Proteins of experimental fishes fed onto supplemented diet and basal diet before infection

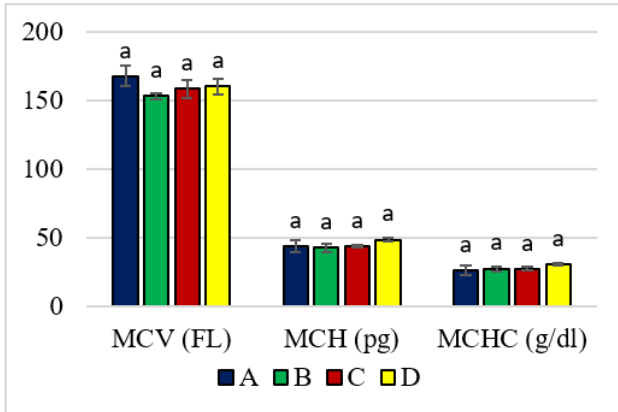

Figure (6): Hematological parameters (MCV (FL), $\mathrm{MCH}(\mathrm{pg}), \mathrm{MCHC}(\mathrm{g} / \mathrm{dl}))$ of experimental infected fishes fed onto supplemented diet and basal diet after infection.

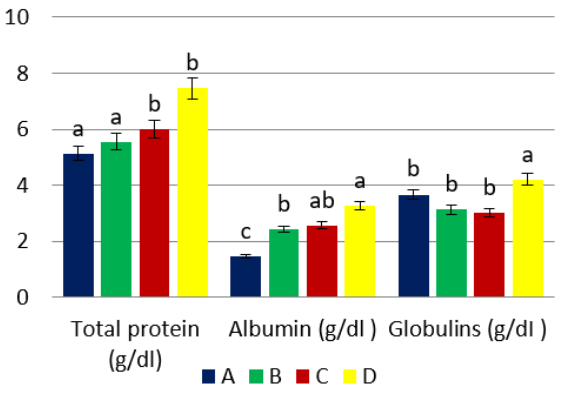

Figure (8): Blood Proteins of experimental infected fish fed onto supplemented diet and basal diet. 


\section{Discussion}

Fish diseases play a role as a limiting factor in fish production and causing mass mortalities and severe economic losses. Curcumin considered as the main constituent of turmeric and act as antimicrobial and immunomostimulant. The mortality rates in experimentally infected Tilapia zillii with Pseudomonas aeruginosa after feeding on basal diet supplemented with different concentrations of curcumin as 2,5 and $10 \mathrm{~g} / \mathrm{kg}$ representing 40,20 and $10 \%$ respectively which were decreased than in control group (80\%). These results attributed to curcumin in diet improve growth performance and immunity which increased the resistance of challenged fish to Pseudomonas aeruginosa. These results were in agreement with Amany Diab et al. (2014) who recorded that the mortality rate in Oreochromis niloticus curcumin treated groups (with 1 and 2\% curcumin in diet) after challenging with Pseudomonas fluorescens were decreased than in control group. Also, Sahu et al. (2008) detected $100 \%$ survivability (no mortality) in Labeo rohuta group fed on $5 \mathrm{~g}$ turmeric /Kg feed for 60 days after challenging with Aeromonas hydrophila and Manal et al. (2014) who reported that the mortality rate in Oreochromis niloticus fed on $5 \mathrm{~g}$ curcumin in diet after challenging with Pseudomonas fluorescens was $0 \%$ (no mortality).
The clinical signs observed in the experimentally infected Tilapia zillii with Pseudomonas aeruginosa were hemorrhages distributed all over the body surface, lower jaw, base of fins, redness around eyes and erosion of fins while the postmortem examination revealed congested to enlarged internal organs. These results were similar to the results of Eissa et al. (2017) and Ezzat et al. (2018).

Regards to the results, the use of turmeric powder as an herbal additive in the diet with different concentrations $2,5,10 \mathrm{~g} / \mathrm{kg}$ basal diet had effect on the hematological parameters belong to the four examined experimental groups after feeding on basal and supplemented diet. The concentration of hemoglobin $(\mathrm{Hb})$, counts of RBCs and counts for WBCs were non significantly increased in fish fed on diet containing 1\% turmeric powder than control group while lymphocyte percentage was tended to be a significant increase in fish fed on diet containing 1\% turmeric powder than fish group fed on diet supplemented with $2 \mathrm{~g} / \mathrm{kg}$ turmeric powder and control group as well as the level of total proteins and globulins were significantly increased in fish fed on diet containing 1 and $0.50 \%$ turmeric powder than other experimental groups $(p<0.05)$. The obtained results were in agreement with Mooraki et al. (2019) who reported that RBC counted, hemoglobin density, hematocrit, $\mathrm{MCV}, \mathrm{MCH}$ 
and $\mathrm{MCHC}$ did not altered significantly among the treatments but the fish fed with 0.3 percent turmeric powder had a higher RBC counts, hemoglobin density and hematocrit compared with the control group and Hassan et al. (2018) who reported that total protein and globulins concentration were significantly higher in fish (Oreochromis niloticus) fed on turmeric supplement compared to the other groups. The increase in globulin levels may be due to the immune stimulant effect of turmeric. Also, Hala et al., (2019) reported that serum albumin, globulin, and total protein were significantly increased in treated fish (Oreochromus niloticus) fed on Turmeric (Curcuma longa) in comparison with control one. The increase in globulin levels may be due to the immune stimulant effect of turmeric. The best values of blood total protein were obtained from curcumin group which agreed with El-Bahr and Saad (2008), Elgendy et al. (2016) and Hassan et al. (2018) who attributed the preferred effect of turmeric to its potent antioxidant and hepatoprotective properties.

The results obtained in this study revealed the effect of addition of Turmeric powder on the hematological parameters as a response to Tilapia zillii with intraperitoneal injection by identified Pseudomonas aeuiginosa which were $\mathrm{RBC}$ count, $\mathrm{Hb}$ concentration, and HCT level increased significantly in the groups fed with curcumin when compared with the control group and non significant differences in the MCV, $\mathrm{MCH}$ and $\mathrm{MCHC}$ values among experimental groups while the total proteins, albumin and globulins were significantly increased in fish fed on diet containing 1\% turmeric powder than other experimental groups. These results were agreement with Amany Diab et al. (2014) who reported that the total proteins and globulin were significantly higher in all treated groups than control which enhanced the resistance of challenged fish with Pseudomonas fluorescens and Abdel Zaher et al. (2009) who showed that, fish fed diet containing different levels as $0.5,1$ and $1.5 \%$ of turmeric seeds meal, significantly increased the serum globulin.. Blood proteins (albumin, and globulin) had a substantial part in fish immunity(Kumar et al., 2007) and the rise of their values were an important indicator that fish had excellent humoral immunity of fish and also associated with a stronger innate response in fish (Wiegertjes et al., 1996) and indicated that, fish were immunologically strong (Nayak et al., 2004).

The present study also revealed the WBCs count, percentage of neutrophils and lymphocytes were significantly increased in fish group fed on diet containing 1\% turmeric powder and infected with Pseudomonas aeuiginosa when compared with other experimental 
groups $(\mathrm{p}<0.05)$ Total and differential leukocytic count, lymphocytes and neutrophils were important indices of nonspecific defense activities in fish (De Pedro et al., 2005). Similar increase in WBCs count, percentage of neutrophils and lymphocytes were recorded by Sivagurunathan et al. (2011) who reported that WBCs count, percentage of neutrophils and lymphocytes were decreased sharply in infected Cirrhinus mrigala, group fed on basal diet than fish group fed on supplemented diet contain two grams of turmeric powder while the percentage of monocytes exhibited highly significant decrease in fish group fed on supplemented diet with turmeric than control group .

\section{References}

Abdel-Tawwab, M. and Fayza E. A. (2017): "Turmeric Powder, Curcuma longa L., in Common Carp, Cyprinus carpio L., Diets: Growth Performance, Innate Immunity, and Challenge against Pathogenic Aeromonas hydrophila Infection" Journal of the world aquaculture society, 48(2): 303-312.

Abdel Zaher, M.M.; Ahmad, H.M.; Amani M. and Asmaa S, (2009): "Effect of Using Dried Fenugreek Seeds as Natural Feed Additives on Growth Performance, Feed Utilization, Whole-body Composition and Entropathogenic Aeromonas Hydrophilachallinge of Monsex Nile Tilapia O. niloticus
(L) Fingerlings. "Australian Journal of Basic and Applied Sciences, 3(2):1234- 1245.

Amany Diab, M.; Saker, O.; Eldakroury, M. and Elseify, M. (2014): "Effects of garlic (Alluim sativum) and curcumin (Turmeric, Curcuma longa Linn) on Nile tilapia immunity." Veterinary Medical Journal (Giza), 60(1):1-19.

Behera, T.: Swain, P., Sahoo, S.K.; Mohapatra, D. and Das, B.K. (2011): "Immunostimulatory effects of curcumin in fish, Labeo rohita (H.)" Indian Journal of Natural Products and Resources, 2(2):184-188.

De Pedro, N.; Guijarro, A.I.; Patioo, M.A.I.;Alvarez, R.M. and Delgado, M.J. (2005): "Daily and seasonal variations in haematological and blood biochemical parameters of Nile Tilapia Oreochromis niloticus (Linnaeus 1757)." Aquaculture research, 36(12): 1185-1196.

Direkbusarakom, S. (2004): "Application of medicinal herbs to aquaculture in Asia, Walailak." Journal of Science and Technology, 1(1):7-14.

Eissa, I. A. M.; Derwa, H.I.M; Mona, M.Abdei Wahab and Kadiga, K.E.M. (2017a): “ Role of some biological pollutants in Fish Disease Occurrence at Lake Temsah" M.V.Sc. thesis, Faculty of Veterinary Medicine, Suez Canal Univeristy.

El-Bahr, S.M., and Saad, T.T. (2008): "Effect of Black cumin 
seeds (Nigella sativa) and/or Turmeric (Curcumin) on hematological, biochemical and Immunological parameters of Mugil cephalus fish vaccinated with Aeromonas

hydrophilia bacterin." In The 13th Scientific Congress, Faculty of Veterinary Medicine, Assiut University, 365-388.

Elgendy, M.Y.; Hakim, A.S.; Ibrahim, B.; Soliman, W.S. and Ali, S.E. (2016): "Immunomodulatory effects of curcumin on Nile tilapia, Oreochromis niloticus and its antimicrobial properties against Vibrio alginolyticus." Journal of Fish Aquatic Science, 11: 206-215.

Ericsson, C., and Nistér, M. (2011): "Blood plasma handling for protein

analysis." Methods in Biobanking, 333-341.

Ezzat, E.M.; Mahmoud, E.; Ibrahim, S.I.; Mohamed, A. and Noha, E.(2018): " Studies on Bacterial Pathogens in Some Marine Fishes in EL Mansoura, Egypt." American Journal of Agricultural and Biological Sciences, 13 (1): 9-15.

Hala, F. Ayoub; El Tantawy, M.M. and Abdel-Latif, H.M.R.(2019): “ Influence of Moringa (Moringa oleifera) and Rosemary (Rosmarinus Officinalis), and Turmeric (Curcuma longa) on Immune parameters and Challenge of Nile tilapia to Aeromonas hydrophila." Life Science Journal,
16(4): 8-15.

Hassan ,A.A.; Yacout, M.H.; Khalel, M.S.; Salma, H. Abu Hafsa; Ibrahim, M. A. R.; Dorina , N.M.; Rahoveanu, A.T. and Dediu, L.(2018): "Effects of some herbal plant supplements on growth performance and the immune response in Nile Tilapia Oreochromis niloticus

" In "Agriculture for Life, Life for Agriculture" Conference Proceedings, Scindo, 8(2): 134141.

Innes, W.T. (1966): "Exotic Aquarium Fishes" $19^{\text {th }}$ Ed. Aquarium incorporated New Jersy. U.S.A.

Iqbal, M.M.; Tajima, K. and Ezura, Y. (1999): "Pathogenicity of Motile Aeromonas Species Isolated from Fishes with Epizootic Ulcerative Syndrome (EUS) in Southeast Asian Countries" Bull. Faculty of Fish. Hokkaido Univeristy, 50(2): 93- 100.

Kumar, V.; Sahu, N.P.; Pal,A.K. and Kumar,S. (2007): "Immunomodulation of Labeo rohita juveniles due to dietary gelatinized and non-gelatinized starch. Fish Shell fish Immunology, (23): 341-353.

Lao, C.D.; Demierre, M.F. and Sondak, V.K. (2006): "Targeting events in melanoma carcinogenesis for the prevention of melanoma." Expert Review of Anticancer Therapy, 6(11): 1559-1568.

Manal M. A. Mahmoud; Maather M.M. El-Lamie, Amina A. 
Dessouki and Mohamed S. Yusuf (2014): "Effect of Turmeric (Curcuma longa) Supplementation on Growth Performance, Feed Utilization, and Resistance of Nile tilapia (Oreochromis niloticus) to Pseudomonas fluorescens Challenge" Journal of Fishery Science and Aquaculture, 1(12): 026-033.

Moghadamtousi, S. Z.; Kadir, H. A.; Hassandarvish, P.; Tajik, H.; Abubakar, S. and Zandi, $K$. (2014): "A review on antibacterial, antiviral, and antifungal activity of curcumin." BioMed Research International,2014.

Mooraki, N.; Batmany, Y.; Zoriehzahra, S.J. and Kakoolaki, Sh. (2019): "Evaluating the effect of using turmeric (Curcuma longa) on growth performance and hematological parameters of the ornamental fish, Green Terror (Andinocara rivulatus) "Journal of Survey in Fisheries Sciences, 5(2) 37-47.

Nayak, A.K.; Das, B.K.; Kohli, M.P. and Mukherjee, S.C. (2004): "The immunosuppressive effect of alpha permethrin on Indian major carp, rohu (Labeo rohita Ham.). "Fish and Shellfish Immunology, 16(1):41-50.

Paramasivam, S.; Thangaradjou, T. and Kannan,L. (2007): "Effect of natural preservatives on the growth of histamine-producing bacteria." Journal of Environmental Biology, 28(2):271-274.

Raida, M. K. and Buchmann, K.
(2009): "Innate immune response in rainbow trout (Oncorhynchus mykiss) against primary and secondary infections with Yersinia rucker O1" Developmental and Comparative Immunology, 33(1): 35-45

Ryan,B. F. and Joiner,B. L. (2005): "Minitab Handbook: update for release 14. $6^{\text {th }}$ edition.

Sahu, S.; Das, B.K.; Mishra, B.K.; Pradhan, J.; Samal, S.K.and Sarangi N. (2008): "Effect of dietary Curcuma longa on enzymatic and immunological profiles of rohu, Labeo rohita (Ham.), infected with Aeromonas hydrophila.

Aquaculture Research, 39 (16): 1720-1730

Selvam, R.; Subramanian, L.; Gayathri, R. and Angayarkanni, N. (1995): "The anti-oxidant activity of turmeric (Curcuma longa)." Journal of Ethnopharmacology, 47 (2):59-67.

Sivagurunathan,A.; Amila Meera, K. and Xavier Innocent, B.(2011): "Investigation of Immunostimulant Potential of Zingiber officinale and Curcuma longa in Cirrhinus mrigala exposed to P.aeruginosa." Haematological Assessment, International Journal of Research in Ayurveda and Pharmacy (IJRAP), 2(3):899-904.

Smith, P.; Hiney, M.P. and Samuelsen, O.B. (1994): "Bacterial resistance to antimicrobial agents used in fish farming." Annual Review of Fish Diseases. 4: 273-313. 
Wiegertjes, G.F.: Stet, R.J.; resistance in fish:" a comparative Parmentier, H.K. and van approach. Developmental and Muiswinkel, W.B. (1996): Comparative Immunology, 20 "Immunogenetics of disease (6):365-381.

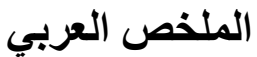

استهدف البحث دراسة نأثير التركيزات المختلفه من بودره الكركم المضافه في عليقة الأسماك علي الئي

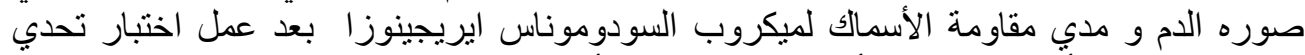

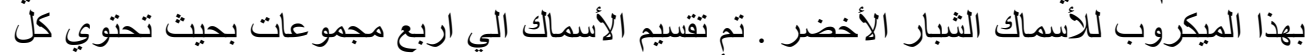

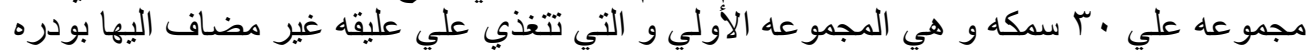

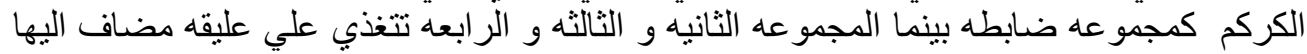

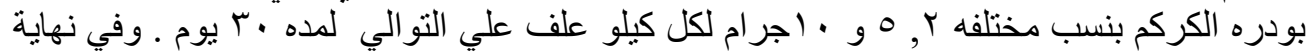

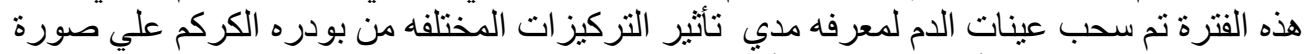

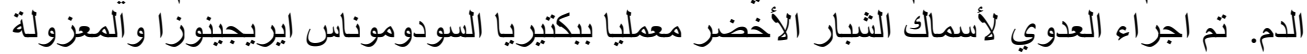

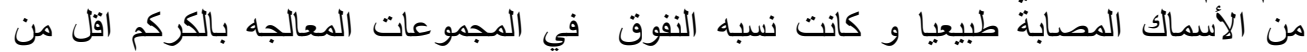

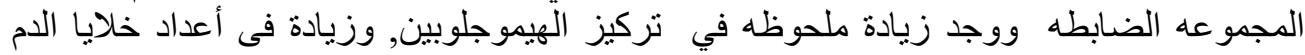

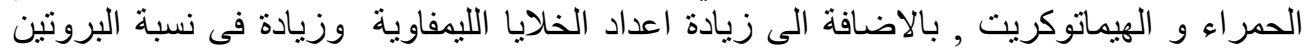
الكلية المتمثلة فى الالبو مين و الجلوبيولين. 